\title{
The impact of the Sino-US trade war on Chinese goods and digital trade from the perspective of the Internet
}

\author{
*Mengyao Wang ${ }^{1, \mathrm{a}}$, Lan Liu ${ }^{2, \mathrm{~b}}$ \\ ${ }^{1}$ Wuhan University of Science and Technology Wuhan, China \\ ${ }^{2}$ Wuhan University of Science and Technology Wuhan, China
}

\begin{abstract}
With the maturity of information technologies such as big data,blockchain,industrial Internet,and artificial intelligence, the Sino-US trade war continues to escalate.It can be predicted that after the Sino-US trade war in goods,a"digital trade war" may have begun quietly.On the one hand,the key to Internet issues is data governance rules, which are related to digital trade and digital economy, and are the key to future national competitiveness; on the other hand, the impact of the trade war on China's trade in goods is also an issue that needs to be discussed.The article found through research that the negative impact of the Sino-US trade war on China is gradually showing. The scale of China's trade import and export has shrunk,and a lot of trade opportunities have been lost.The prediction of "internet fragmentation" is becoming a reality.I analyzed the countermeasures to deal with the trade war from the aspects of conducting trade negotiations, expanding internal demand,and handling data governance issues.
\end{abstract}

\section{Analysis of the status quo of the Sino- US trade war}

\subsection{The United States frequently imposes tariffs and the trade situation is severe}

The imposing of import tariffs on China,the organization of unconventional investigations of anti-globalization thoughts, and the implementation of "double reverse"policies and other trade protection measures have become the main theme of the US trade policy towards China.Taking the United States' announcement of the"301 Investigation"against China in August 2017 as an example,the United States can conduct investigations into other countries' trade practices in order to obtain trade compensation in accordance with unconventional investigation clauses,thereby achieving the purpose of protecting local companies.In essence,the "301 Investigation" is a unilateral trade sanction by the United States against China, which clearly violates the multilateral trade agreement advocated by the World Trade Organization.As of August 2019, the United States has initiated 47 unconventional investigations against Chinese companies,causing huge economic losses to Chinese export companies.

\subsection{Trade frictions are involved in large numbers and large amounts}

Since the United States initiated anti-dumping investigations against Chinese menthol in 1980,the United
States has initiated more frequent trade remedy cases against China.From 1980 to 2019, among the trade remedy cases initiated by the United States against China,there were 175 anti-dumping cases, 89 anti-subsidy cases, 12 safeguard measures,and 42 special safeguard measures.Among them, in 2017,among the relief cases initiated by the United States against China,there were 24 anti-dumping cases,a year-on-year increase of $29.1 \%, 22$ countervailing cases, a year-on-year increase of $36.4 \%$,and 2 safeguard measures.In 2018,Sino-US trade relations entered a cold winter period and trade frictions escalated.In addition,the amount involved in trade frictions is also increasing year by year.

\section{Main reasons for the outbreak of the Sino-US trade war}

\subsection{Serious imbalance in Sino-US trade}

The serious imbalance in Sino-US trade is the direct cause of Trump's initiation of the trade war ${ }^{[3]}$.The US requires China to reduce the US trade deficit with China by US\$100 billion and further open the market ${ }^{[3]}$. The trade situation between China and the United States currently shows a surplus in China's trade in goods and a deficit in trade in services, while the US has a total trade deficit in goods of 891.3 billion US dollars,even if its service trade achieves a surplus,its total trade deficit is US\$621 billion,setting a new historical record since the founding of the People's Republic of China 243 years ago. This reflects the comparative advantages of China and the United States to a certain extent.According to the U.S.-

a*Corresponding author: 719482433@qq.com

bCorresponding author: 824747224@qq.com 
China Economic Report issued by Cathay Bank and UCLA Anderson Forecast Center,the United States' largest trading partner in 2017 was China,with a total transaction volume of US\$636 billion.Among them,imports are 506 billion US dollars and exports are 130 billion US dollars.Moreover,the US-China trade deficit is significantly larger than other countries ${ }^{[7]}$. According to the report, the total merchandise trade deficit of the United States in 2017 was US\$796 billion,of which the trade deficit with China was US\$375 billion,accounting for $47 \%$ of the total trade deficit.It is higher than the sum of the eight countries ranked second to ninth $(44 \%)^{[4]}$; and in 2017 , China had a surplus of US\$276 billion in goods trade with the United States,accounting for $66 \%$ of China's goods trade surplus. That is, Trump has a factual basis for playing the trade deficit card.But if the United States does not abandon the international currency function of the US dollar ${ }^{[1]}$, and only relies on reducing the scale of imports from other countries and its own re-industrialization strategy, the US trade balance problem will still be difficult to resolve fundamentally ${ }^{[1]}$.

\section{The negative impact of the Sino-US trade war on China}

\subsection{The overall import and export scale has shrunk and the growth rate has slowed}

According to data from the General Administration of Customs of China, as shown in Table 1,from 2017 to 2018 , China's total import and export of goods was US\$4.44 trillion, of which total exports were US\$2.42 trillion and imports totaled US\$2.02 trillion.From 2018 to 2019 , China's total imports and exports of goods were US\$4.37 trillion,a year-on-year decrease of $1.58 \%$; of which exports totaled US\$2.40 trillion, a decrease of $0.83 \%$; and imports totaled US\$1.97 trillion, a decrease of $2.48 \%$. The overall scale of imports and exports has shrunk to a certain extent. We can see from the monthly year-onyear growth rate that it was $15.81 \%$ from April 2017 to March 2018,but we see that the average growth rate of imports and exports from April 2018 to March 2019 was $12 \%$.Last year,it dropped by $3.81 \%$; the average growth rate of exports was $7.70 \%$,down $3.28 \%$ year-on-year,and the average growth rate of imports was $10.47 \%$,down $4.88 \%$ year-on-year. What's more, in February 2019, the year-onyear growth rate of exports was as low as $-20.7 \%{ }^{[7]}$.From this we can see that since the beginning of the Sino-US trade friction in March 2018, not only the scale of China's imports and exports of goods has shrunk, but also the growth rate of imports and exports has been greatly affected.
Table1. China's total trade in goods( Unit: trillion US dollars)

\begin{tabular}{|c|c|c|c|c|c|c|c|}
\hline Year & $\begin{array}{c}\text { Total } \\
\text { import } \\
\text { and } \\
\text { export }\end{array}$ & $\begin{array}{c}\text { Year- } \\
\text { on-year } \\
\text { growth }\end{array}$ & $\begin{array}{c}\text { Total } \\
\text { export }\end{array}$ & $\begin{array}{c}\text { Export } \\
\text { growth } \\
\text { rate }\end{array}$ & $\begin{array}{c}\text { Total } \\
\text { import }\end{array}$ & $\begin{array}{c}\text { Import } \\
\text { growth } \\
\text { rate }\end{array}$ & $\begin{array}{c}\text { Trade } \\
\text { balance }\end{array}$ \\
\hline 2015 & 3.71 & $\begin{array}{c}- \\
13.80 \% \\
\end{array}$ & 2.14 & $-8.53 \%$ & 1.57 & $\begin{array}{c}- \\
20.09 \% \\
\end{array}$ & 0.58 \\
\hline 2016 & 3.49 & $-5.91 \%$ & 1.99 & $-7.01 \%$ & 1.50 & $-4.46 \%$ & 0.49 \\
\hline 2017 & 3.96 & $13.47 \%$ & 2.22 & $11.56 \%$ & 1.74 & $16.00 \%$ & 0.48 \\
\hline 2018 & 4.44 & $12.12 \%$ & 2.42 & $9.01 \%$ & 2.02 & $16.09 \%$ & 0.40 \\
\hline 2019 & 4.37 & $-1.58 \%$ & 2.40 & $-0.83 \%$ & 1.97 & $-2.48 \%$ & 0.43 \\
\hline
\end{tabular}

\subsection{China's trade surplus with the US has decreased, and China has lost a lot of trade opportunities}

According to China Customs statistics, as shown in Table 2,in 2019, China's import and export trade with the US was US\$541.22 billion,a year-on-year decrease of $14.6 \%$; while China's exports to the US were US $\$ 418.51$ billion, a year-on-year decrease of $12.5 \%$.This reduction in exports to the United States amounted to more than 52 billion U.S. dollars ${ }^{[5]}$, that is to say, Chinese companies have lost 52 billion U.S. dollars of production and trade opportunities $^{[5]}$; China's trade scale has shrunk, and the negative impact is expanding.In the same period, China's imports from the United States were US\$122.71 billion, a year-on-year decrease of $20.9 \%$.Because of this, China's imports from the US decreased by more than US $\$ 25$ billion.Similarly, from the perspective of the United States,American companies also The loss of 25 billion US dollars of production and trade opportunities is mutual.However,to some extent, China's lost production and trade opportunities are greater than those of the United States $^{[6]}$.For 2019 , the negative impact of the trade war is slowly deepening and unstoppable. In 2018,China's exports to the United States amounted to 478.4 billion U.S. dollars ${ }^{[6]}$.Due to China's basic lack of growth in imports to the U.S. and double-digit growth in exports to the U.S., the trade surplus widened to 323.3 billion U.S. dollars, a year-on-year increase of $17.2 \%$.U.S. statistics show that China's trade surplus will exceed this number.This is probably because the U.S. recognized China's trade surplus should exceed $\$ 323.3$ billion. However,by the end of 2019,China's trade surplus with the United States had been controlled at 295.8 billion U.S. dollars,falling to a level below 300 billion U.S. dollars,a year-on-year decrease of 27.5 billion U.S. dollars. This result is exactly what the United States wants to achieve through tariff adjustments ${ }^{[2]}$. 
Table2. China's import and export trade volume with the US (Unit: US\$100 million )

\begin{tabular}{|c|c|c|c|c|c|c|c|}
\hline Project & $\begin{array}{c}\text { Total import and export } \\
\text { trade between China } \\
\text { and the United States }\end{array}$ & $\begin{array}{c}\text { Year-on-year } \\
\text { growth }\end{array}$ & $\begin{array}{c}\text { Total export } \\
\text { trade }\end{array}$ & $\begin{array}{c}\text { Export growth } \\
\text { rate }^{[2]}\end{array}$ & $\begin{array}{c}\text { Total import } \\
\text { trade }\end{array}$ & $\begin{array}{c}\text { Import growth } \\
\text { rate }\end{array}$ & $\begin{array}{c}\text { (2] } \\
\text { trade } \\
\text { surplus }\end{array}$ \\
\hline 2015 & 5583.9 & $0.59 \%$ & 4096.5 & $3.43 \%$ & 1487.4 & $-6.48 \%$ & 2609.1 \\
\hline 2016 & 5785.9 & $3.62 \%$ & 4628.1 & $12.98 \%$ & 1157.8 & $-22.16 \%$ & 3470.3 \\
\hline 2017 & 5836 & $0.80 \%$ & 4297 & $-7.15 \%$ & 1539 & $32.92 \%$ & 2758 \\
\hline 2018 & 6335.4 & $8.60 \%$ & 4784.2 & $11.34 \%$ & 1551.2 & $0.79 \%$ & 3233 \\
\hline 2019 & 5412.2 & $-14.60 \%$ & 4185.1 & $-12.52 \%$ & 1227.1 & $-20.89 \%$ & 2958 \\
\hline
\end{tabular}

\subsection{China's exports to the U.S. have declined, and agricultural products and mechanical and electrical products have declined significantly}

According to the analysis of major categories of customs statistics, in 2019, China's exports to the United States,without exception,all major categories of commodities have generally declined.As shown in Table 3 ,agricultural products fell by $24.3 \%$, auto parts and accessories fell by $22.8 \%$,telephones fell by $11.6 \%$,hightech products fell by $13.8 \%$, and electromechanical products fell by $13.5 \%$. The decline in exports of furniture and parts,automatic data processing equipment, textile yarns,and clothing were $20.1 \%, 8.1 \%, 8.6 \%$, and $6.3 \%$,respectively.Plastic products experienced a negative growth of $0.2 \%$, a slight decline.Due to the negative growth of the above-mentioned categories, exports directly reduced by more than 60 billion US dollars.However,under normal circumstances,China's exports to the United States will not only grow negatively,but also positive growth.It is conceivable that the negative impact of the trade war will definitely exceed China's exports to the United States by 60 billion US dollars,or even a lot. What needs special attention is that for some light industrial textiles and garments, telephones and other manufactured products, and even some mechanical and electrical products.U.S. importers have been seeking alternative manufacturers in Southeast Asia and other countries outside of China.If they achieve their goals,it will be difficult for Chinese exports to squeeze into the U.S. market in the future.This situation is very unfavorable for China.

Table3. Decline of China's exports to the US in 2019

\begin{tabular}{|c|c|}
\hline Export goods & Rate of decline \\
\hline Agricultural products & $24.30 \%$ \\
\hline automobile parts & $22.80 \%$ \\
\hline Telephone & $11.60 \%$ \\
\hline High-tech products & $13.80 \%$ \\
\hline electronics & $13.50 \%$ \\
\hline Furniture and parts & $20.10 \%$ \\
\hline
\end{tabular}

\begin{tabular}{|c|c|}
\hline $\begin{array}{c}\text { Automatic data processing equipment } \\
\text { and its components }\end{array}$ & $\mathbf{8 . 1 0 \%}$ \\
\hline Textile yarn and products & $\mathbf{8 . 6 0 \%}$ \\
\hline Clothing and clothing accessories & $\mathbf{6 . 3 0 \%}$ \\
\hline plastic products & $\mathbf{0 . 2 0 \%}$ \\
\hline \multicolumn{2}{|c|}{ Data source: General Administration of Customs of Chin }
\end{tabular}

\subsection{China's imports from the U.S. decreased,and crude oil and aircraft dropped significantly}

According to the analysis of customs statistics,from January to November 2019, China's imports from the United States $^{[2]}$, with the exception of integrated circuits still having an increase of $14.7 \%$,all other major categories of goods have seen a substantial decline.As shown in Table 4 , the decrease of crude oil was $51.2 \%$,the decrease of grain was $28.6 \%$, the decrease of agricultural products was $22.1 \%$,the decrease of aircrafts and other aircraft was $57.3 \%$,automobiles,primary plastics, electromechanical products,automatic control instruments for measurement and analysis, and high-tech.The decline in imports of products were $20.3 \%, 18 \%, 15.9 \%, 10.1 \%$ and $14.5 \%$. The negative growth of the above categories directly reduced imports to around US\$29 billion. Among them, the reduction in imports of food and agricultural products reached more than US\$4 billion, which had an impact on the exports of American farmers' agricultural products.In addition, the reduction in imports of mechanical and electrical products from the US alone exceeded 100.Billion US dollars,reducing imports of high-tech products by more than 6 billion US dollars. Containing China's technological progress,and doing everything possible to prevent the full rise of China's technology and economy from becoming a strategic choice for the United States $^{[10]}$.

Table4. line in China's imports from the United States in 2019

\begin{tabular}{|c|c|}
\hline Imported Products & Rate of decline \\
\hline crude & $51.20 \%$ \\
\hline food & $28.60 \%$ \\
\hline Agricultural products & $22.10 \%$ \\
\hline
\end{tabular}




\begin{tabular}{|c|c|}
\hline Aircraft and other aircraft & $57.30 \%$ \\
\hline car & $20.30 \%$ \\
\hline Primary form plastic & $18 \%$ \\
\hline electronics & $15.90 \%$ \\
\hline $\begin{array}{c}\text { Measurement, detection and } \\
\text { analysis automatic control } \\
\text { instrument }\end{array}$ & $10.10 \%$ \\
\hline High-tech products & $14.50 \%$ \\
\hline
\end{tabular}

\section{China's countermeasures and conclusions in response to the Sino-US trade war}

\subsection{China's response to the Sino-US trade war}

\subsubsection{Actively carry out trade negotiations to resolve trade differences between China and the United States}

Over the years, due to the close economic and trade exchanges between China and the United States, the two sides have been completely intertwined,forming a community of interests of "you are in me and you are in me".The Sino-US trade surplus continues to expand,mainly due to the severe restrictions on the export of high-tech products to China by the United States and inappropriate trade protectionist measures taken by the United States. The levy of tariffs is actually an increase in taxes on domestic enterprises and consumers, and the result can only be a situation of "harming the enemy by one thousand,and harming oneself by 800 ."The more intense the Sino-US trade friction,the greater the harm to the two countries. China and the United States should properly handle this trade friction through trade negotiations.For China,one is to further open up,establish a fairer market economy,and achieve high-quality economic growth in China;second is to steadily advance the reform of domestic systems and mechanisms, actively integrate with the international market, and achieve smooth export of domestic products.

\subsubsection{Active efforts to find new alternative products and markets}

China must be prepared with both hands.It must not only pay attention to negotiation strategies, but also prepare for the worst and prepare for the worst ${ }^{[9]}$. The first is to strengthen the building of independent innovation capabilities and find alternative products for the products restricted from the United States.The honeymoon period of Sino-US economic and trade relations has passed.On the basis of maintaining continued cooperation,appropriate "decoupling" is an option that should be considered.Second,China can strengthen economic and trade cooperation and exchanges with the European Union,ASEAN, Japan,South Korea and other countries to expand export markets.Currently,China is implementing the "One Belt One Road" initiative.In the future,countries and regions along the route will become a new direction for China's foreign trade exports. The relevant economic decisions of the US government are not in line with the mainstream trend of world historical development,and will not change the direction of economic globalization and world economic integration.According to relevant data,China's imports and exports to countries along the "Belt and Road" have increased significantly ${ }^{[8]}$.This countermeasure has important practical significance for the healthy,sustainable and harmonious development of China's import and export trade.

\subsubsection{Actively expand domestic demand}

Convert a large number of exports into huge domestic consumer demand.In the future, China's domestic consumption potential and consumer market are huge,and supply-side structural reforms will provide strong competitiveness for enterprises and products. China must be determined,confident, and do its own thing well,and respect the WTO.Under the premise of rules,strengthen economic and trade exchanges with countries around the world,improve quality and efficiency in economic development,and seek new support points for future development under the guidance of high-tech.

\subsection{Conclusion}

\subsubsection{The Sino-US trade war will worsen the terms of trade between China and the US}

The Sino-US trade war will worsen the terms of trade between China and the United States.Relatively speaking, China will lose even more, and will improve the terms of trade of other countries and regions in the world to varying degrees, resulting in positive externalities. The main reason is that China and the United States have transferred a large amount of exports to these countries and regions.In order to maintain their price advantage in overseas markets,they can only choose to lower their export prices.

\subsubsection{Promote trade exchanges between China and countries along the Belt and Road}

The reduction in China's import and export trade with the United States has reversely promoted trade exchanges with the "Belt and Road" countries.Since the implementation of the "Belt and Road"initiative, China has become increasingly close in trade with countries along the"Belt and Road", especially the trade surplus with Central Asian countries has been increasing year by year.In order to make China's imports and exports of countries along the "Belt and Road" more in line with national trade development plans and strategic implementation, it is necessary to have a clearer understanding of the structure of imports and exports of countries along the "Belt and Road" ${ }^{[8]}$.Only in this way can we put forward trade policies and recommendations that are more in line with national conditions and actual 
conditions on this basis,which has important practical significance for the healthy,sustained and harmonious development of China's foreign trade.

\section{References}

1. Qing Guo, Weiguang Chen, Research on the Impact of Sino-US Trade Frictions on China's International Trade and Countermeasures[J]. Economic and Social System Comparison, 2019 (5): 78-90.

2. Bin Zhang,"China's Economic Transition Syndrome",China \& World Economy, 2015(6):12-15.

3. Zhongliang Deng,"Sino-U.S.Trade Friction Viewed from the Sino-U.S. Trade Structure",China Circulation Economy, 2018 (10): 80-92.

4. Yan Wang,The impact of Sino-US trade frictions on my country's international trade exports[J].Heilongjiang Branch 2018(11): 159-160.

5. Jiahui Ding,Bingxin Hou,Mengdan Jiao,et al.Research on Sino-US trade friction and its countermeasures[J].Modern Business, 2017(1): 57-58.

6. Yuan Tao,"On China's Trade Surplus",Springer Science and Business Media LLC,2014(5):35-38.

7. Xiao Li, Sino-US trade imbalance and Trump's purpose of launching a trade war[J]. Nankai Journal (Philosophy and Social Sciences Edition), 2018 (3): 256-259.

8. Huan Wang,"Research on National Scientific Research Cooperation between China and the "One Belt and One Road"-Based on the Frontier Gravity Model",American Journal of Industrial and Business Management,2019 (10):56-59.

9. Li Zhou,"Sino-US Trade Disputes: Technological Blockade and Protectionism", International Economics and Trade Exploration,2018 (10): 88-104.

10. Wen Li,"Deep objective reasons for the sharpening of Sino-US trade frictions", "People's Forum· Academic Frontiers", 2018 (16): 19-29. 